\title{
Gastroenterology
}

DOI: 10.1159/000452209
Publisnea oninne: November 25, 2016

This article is licensed under the Creative Commons Attribution-NonCommercial 4.0 International License (CC BY-NC) (http://www.karger.com/Services/OpenAccessLicense). Usage and distribution for commercial purposes requires written permission.

\section{Drug-Induced Liver Injury Associated with Complementary and Alternative Medicines}

\author{
Koji Takahashi ${ }^{\mathrm{a}}$ Tatsuo Kanda $^{\mathrm{a}}$ Shin Yasui ${ }^{\mathrm{a}}$ Yuki Haga $^{\mathrm{a}}$ \\ Junichiro Kumagai ${ }^{a}$ Reina Sasaki $i^{a}$ Shuang $W^{a}$ Shingo Nakamoto ${ }^{a, b}$ \\ Masato Nakamura ${ }^{a}$ Makoto Arai ${ }^{a}$ Osamu Yokosuka ${ }^{a}$ \\ ${ }^{a}$ Department of Gastroenterology and Nephrology, Chiba University, Graduate School of \\ Medicine, Chiba, Japan; ${ }^{b}$ Department of Molecular Virology, Chiba University, Graduate \\ School of Medicine, Chiba, Japan
}

\section{Keywords}

Alternative medicine $\cdot$ Complementary medicine $\cdot$ Drug-induced liver injury

\begin{abstract}
A 24-year-old man was admitted due to acute hepatitis with unknown etiology. After his condition and laboratory data gradually improved with conservative therapy, he was discharged 1 month later. Two months after his discharge, however, liver dysfunction reappeared. After his mother accidentally revealed that he took complementary and alternative medicine, discontinuation of the therapy caused his condition to improve. Finally, he was diagnosed with a recurrent drug-induced liver injury associated with Japanese complementary and alternative medicine. It is important to take the medical history in detail and consider complementary and alternative medicine as a cause of liver disease.
\end{abstract}

(C) 2016 The Author(s)

Published by S. Karger AG, Basel 


\section{Case Reports in Gastroenterology}

\section{Introduction}

Acute liver failure (ALF) is often a life-threatening disease [1] and, in some cases of ALF, the etiology is not clear. Because it is difficult to specifically treat those patients with an unknown etiology, their prognosis seems poor compared with patients with a known etiology such as hepatitis A virus, hepatitis B virus, or an autoimmune mechanism. It is possible that drug-induced liver injury (DILI) could occur with the use of any drug. DILI could cause ALF, occasionally leading to death [2-4]. Moreover, it is difficult to identify the drug causing the liver injury, and so there is a lack of reliable markers to facilitate and establish the diagnosis of DILI $[5,6]$.

Due to an increase in health consciousness and internet use, complementary and alternative medicine is readily available. Complementary and alternative medicine also occasionally causes liver injury [7-10]. Recent reports of DILI by complementary and alternative medicine are increasing in the United States [7] and Japan [10]. We describe a 24-year-old male patient who had DILI associated with complementary and alternative medicine.

\section{Case Report}

A 24-year-old Japanese man visited our hospital after several days of fatigue and signs of jaundice. He had no previous history of liver diseases, rheumatic diseases, surgeries, transfusions, abuse of illegal drugs, or drug allergies. He was a social drinker of alcohol. He had no family history of liver diseases or rheumatic diseases. He was a graduate student and did not work. At the end of August 2015, he was first admitted to our hospital for a careful examination of his liver disease (Fig. 1). On admission, his body length, body weight, and body mass index were $1.75 \mathrm{~m}, 60.0 \mathrm{~kg}$, and 20.0, respectively. On physical examination, no ascites or leg edema was observed. His liver and spleen were not swollen. His consciousness was alert. Laboratory findings on his first admission are shown in Table 1. Neither viral hepatitis markers nor autoantibodies were positive. An abdominal ultrasound on the first admission demonstrated no chronic liver disease or ascites. A first liver biopsy specimen showed that the hepatic architecture was preserved and the histology was compatible to that of acute hepatitis. There were no signs of chronic liver disease (Fig. 2). We diagnosed him with acute hepatitis of unknown etiology at this admission. Because conservative treatment made his transaminases lower, he was discharged from our hospital 1 month after the first admission (aspartate aminotransferase [AST] $23 \mathrm{IU} / \mathrm{L}$, alanine transaminase [ALT] $33 \mathrm{IU} / \mathrm{L}$, and $\gamma$ glutamyltransferase [ $\gamma$-GTP] $111 \mathrm{IU} / \mathrm{L}$ ) (Fig. 1). Two months after the first admission, his laboratory data were almost normal (AST $20 \mathrm{IU} / \mathrm{L}$, ALT $14 \mathrm{IU} / \mathrm{L}$, and $\gamma$-GTP $49 \mathrm{IU} / \mathrm{L}$ ). At an outcome clinic 3 months after his first admission, his liver function tests were abnormal (AST $70 \mathrm{IU} / \mathrm{L}$, ALT $65 \mathrm{IU} / \mathrm{L}$, and $\gamma$-GTP $30 \mathrm{IU} / \mathrm{L}$ ). At an outcome clinic 4 months after his first admission, his liver function tests were worse (AST 133 IU/L, ALT 294 IU/L, and $\gamma$-GTP 46 $\mathrm{IU} / \mathrm{L}$ ). At this time, we suspected a chronic active hepatitis such as autoimmune hepatitis and introduced prednisolone $15 \mathrm{mg}$ daily and ursodeoxycholic acid $600 \mathrm{mg}$ daily; however, his liver tests were not improved at 1 week (AST 438 IU/L, ALT 1104 IU/L, and $\gamma$-GTP 119 $\mathrm{IU} / \mathrm{L})$. 


\section{Case Reports in Gastroenterology}

In January 2016, he was admitted to our hospital for a second time for further examination of his liver disease (Fig. 1). On admission, his body length, body weight, and body mass index were $1.75 \mathrm{~m}, 59.0 \mathrm{~kg}$, and 19.3, respectively. Laboratory findings on his second admission are shown in Table 2. During the medical interview, his mother accidentally told us that he took complementary and alternative medicine (LEVERCOL ${ }^{\circledR}$, Nippo-Yakuhin, Tokyo, Japan, and Jacko ${ }^{\circledR}$, Nippo-Yakuhin) temporarily for a single use before the first admission. However, before finding out his liver dysfunction at an outcome clinic and before his second admission, interestingly, this patient did not admit to use of the drugs. A liver biopsy was reperformed, and the results were compatible with acute hepatitis due to a drug (Fig. 3). Discontinuation of LEVERCOL ${ }^{\circledR}$ and Jacko ${ }^{\circledR}$ led to improvement in his condition and liver dysfunction. We diagnosed him as DILI with complementary and alternative medicine (LEVER$\mathrm{COL}^{\circledR}$ and Jacko ${ }^{\circledR}$ ). His condition gradually improved with the use of temporary corticosteroids and he was discharged 2 months after the second admission (AST 15 IU/L, ALT 32 IU/L, and $\gamma$-GTP $131 \mathrm{IU} / \mathrm{L}$ ). Six months after the second admission, his liver function tests had completely returned to normal ranges without any medication (AST 20 IU/L, ALT 21 IU/L, and $\gamma$-GTP 15 IU/L).

\section{Discussion}

The presented case took complementary and alternative medicine (LEVERCOL ${ }^{\circledR}$ and Jacko $^{\circledR}$ ) before every appearance of his liver dysfunction. Discontinuation of LEVERCOL ${ }^{\circledR}$ and Jacko ${ }^{\circledR}$ could have led to improvement of his condition and liver dysfunction. This patient did not admit the use of these medicines as drugs, but his mother told us about them, resulting in the accurate diagnosis.

LEVERCOL ${ }^{\circledR}$ is an herbal preparation containing fish liver extract that is available only in Japan and used for analeptics, weak constitution, and nutritional supplementation [11, 12]. It is reported that an 84-year-old male patient who developed subacute fulminant hepatitis was taking LEVERCOL ${ }^{\circledR}$ with other drugs [11]. Jacko ${ }^{\circledR}$ is used for physical exhaustion, weak constitution, and nutritional supplementation [13]. These complementary and alternative medicines are able to be obtained through the internet. We do not know which drugs were responsible for his liver dysfunction.

In Asian communities, the majority (74\%) of patients with hepatotoxicity associated with the use of complementary and alternative medicine were above 40 years of age and $49 \%$ were male [14], although the present case was a 24-year-old man. Teo et al. [14] also reported that traditional Chinese medicine, health supplements, and other traditional medicines, including Malay Jam and Indian Ayurveda products, caused liver injury in 62, 28, and $11 \%$, respectively. LEVERCOL ${ }^{\circledR}$ and Jacko ${ }^{\circledR}$ are health supplements $[11,13]$. They also report that $60 \%$ and $5 \%$ of patients developed an acute hepatitis type or cholestatic hepatitis type, respectively [14], corresponding with the present report that LEVERCOL ${ }^{\circledR}$ and Jacko ${ }^{\circledR}$ induced acute hepatitis. In the United States, out of 647 adults with liver disease, $41 \%$ reported using complementary and alternative medicine, compared with $33 \%$ in adults without liver disease [15]. The majority of users believe that complementary and alternative medicine could improve their health [15]. 
Of interest, in the present case, the use of complementary and alternative medicine caused liver dysfunction, such as chronic active hepatitis, although we excluded autoimmune hepatitis by liver biopsy. Clinicians should consider DILI in patients with repeated liver dysfunction. Our report suggests that it is important to perform a medical interview with the patients, as well as their family, even if the patient is an adult.

Many factors cause liver dysfunction, including fatty changes, drugs, viruses, and autoimmune mechanisms. Often, the cause is unclear early in the course. If the cause is unclear, ultrasound-guided liver biopsy should be performed. In spite of its limitations, the liver biopsy still remains invaluable and can provide important information for diagnosis and management. In the present patient, both liver biopsy specimens were compatible with acute hepatitis due to drugs.

In Japan, the Digestive Disease Week Japan (DDW-J) 2004 score is widely used for confirmation of the causality of DILI [16]. It classifies the possibility by the point total. Less than 2 points is a low possibility, 3-4 points is possible, and more than 5 points is potentially high. This score is highly sensitive and specific [16]. LEVERCOL ${ }^{\circledR}$ and Jacko ${ }^{\circledR}$ both had 10 points, but it is difficult to identify which one of them was the cause. Additionally, they consist of many ingredients and additives $[11,13]$.

It has been reported that complementary and alternative medicine-induced DILI is at least as severe in presentation as that observed in prescription medicine-induced DILI, with higher rates of transplantation and lower transplant-free survival in those who progress to ALF [17]. In general, it is possible that patients may not report taking complementary or alternative medicine as a drug. It may be difficult to determine the cause of liver dysfunction in these patients. In conclusion, attention should be paid to complementary and alternative medicines in patients possessing liver dysfunction with an unknown etiology. A medical interview should be performed with the patients, as well as with their family, to lead to the accurate diagnosis.

\section{Acknowledgements}

The authors thank all Chiba University Hospital's staff for the patient's care.

\section{Statement of Ethics}

There are no ethical conflicts to declare.

\section{Disclosure Statement}

Tatsuo Kanda received a research grant from Chugai Pharmaceutical and MSD; Osamu Yokosuka received a research grant from Chugai Pharmaceutical, Bayer, MSD, DaiichiSankyo, Tanabe-Mitsubishi, Bristol-Myers Squibb, Taiho Pharmaceutical, and Gilead Sciences; Koji Takahashi, Shin Yasui, Yuki Haga, Junichiro Kumagai, Reina Sasaki, Shuang Wu, Shingo Nakamoto, Masato Nakamura, and Makoto Arai declare that they have no conflict of interest. 


\section{Case Reports in Gastroenterology}

Case Rep Gastroenterol 2016;10:706-713

(C) 2016 The Author(s). Published by S. Karger AG, Base www.karger.com/crg

Takahashi et al.: Drug-Induced Liver Injury Associated with Complementary and Alternative Medicines

\section{References}

1 Mochida S, Takikawa Y, Nakayama N, Oketani M, Naiki T, Yamagishi Y, Fujiwara K, Ichida T, Tsubouchi $\mathrm{H}$ : Classification of the etiologies of acute liver failure in Japan: a report by the Intractable HepatoBiliary Diseases Study Group of Japan. Hepatol Res 2014;44:365-367.

-2 Ostapowicz G, Fontana RJ, Schiødt FV, Larson A, Davern TJ, Han SH, McCashland TM, Shakil AO, Hay JE, Hynan L, Crippin JS, Blei AT, Samuel G, Reisch J, Lee WM; U.S. Acute Liver Failure Study Group: Results of a prospective study of acute liver failure at 17 tertiary care centers in the United States. Ann Intern Med 2002;137:947-954.

-3 Fontana RJ, Seeff LB, Andrade RJ, Björnsson E, Day CP, Serrano J, Hoofnagle JH: Standardization of nomenclature and causality assessment in drug-induced liver injury: summary of a clinical research workshop. Hepatology 2010;52:730-742.

-4 Kanda T, Yokosuka O, Fujiwara K, Saisho H, Shiga H, Oda S, Okuda K, Sugawara Y, Makuuchi M, Hirasawa H: Fulminant hepatic failure associated with triazolam. Dig Dis Sci 2002;47:1111-1114. Chalasani N, Björnsson E: Risk factors for idiosyncratic drug-induced liver injury. Gastroenterology 2010;138:2246-2259.

-6 Lucena MI, García-Cortés M, Cueto R, Lopez-Duran J, Andrade RJ: Assessment of drug-induced liver injury in clinical practice. Fundam Clin Pharmacol 2008;22:141-158.

7 Navarro VJ, Barnhart H, Bonkovsky HL, Davern T, Fontana RJ, Grant L, Reddy KR, Seeff LB, Serrano J, Sherker AH, Stolz A, Talwalkar J, Vega M, Vuppalanchi R: Liver injury from herbals and dietary supplements in the U.S. Drug-Induced Liver Injury Network. Hepatology 2014;60:1399-1408. Kanda T, Yokosuka O, Okada O, Suzuki Y, Saisho H: Severe hepatotoxicity associated with Chinese diet product 'Onshidou-Genbi-Kounou'. J Gastroenterol Hepatol 2003;18:354-355.

-9 Adachi M, Saito H, Kobayashi H, Horie Y, Kato S, Yoshioka M, Ishii H: Hepatic injury in 12 patients taking the herbal weight loss AIDS Chaso or Onshido. Ann Intern Med 2003;139:488-492.

10 Hisamochi A, Kage M, Ide T, Arinaga-Hino T, Amano K, Kuwahara R, Ogata K, Miyajima I, Kumashiro R, Sata M, Torimura T: An analysis of drug-induced liver injury, which showed histological findings similar to autoimmune hepatitis. J Gastroenterol 2016;51:597-607.

11 Nippo-yakuhin: http://www.nippo-yakuhin.jp/hinmoku_detail/01210.html. Accessed on 2016/8/8 (in Japanese).

12 FDA U.S. Food and Drug Administration: http://www.accessdata.fda.gov/drugsatfda_docs/nda/2008/022206s000_MedR_P2.pdf. Accessed on $2016 / 8 / 8$

13 Nippo-yakuhin: http://www.nippo-yakuhin.jp/jacko/element. Accessed on 2016/8/8 (in Japanese)

14 Teo DC, Ng PS, Tan SH, Lim AT, Toh DS, Chan SY, Cheong HH: Drug-induced liver injury associated with Complementary and Alternative Medicine: a review of adverse event reports in an Asian community from 2009 to 2014. BMC Complement Altern Med 2016;16:192.

15 Henson JB, Brown CL, Chow SC, Muir AJ: Complementary and alternative medicine use in United States adults with liver disease. J Clin Gastroenterol 2016, Epub ahead of print.

16 Takikawa H, Onji M, Takamori Y, Murata Y, Taniguchi H, Ito T, Watanabe M, Ayada M, Maeda N, Nomoto M, Murata H, Ohmori S, Hisamochi A, Sumida T: Proposal of diagnostic criteria for drug-induced hepatic injury revised by the DDW-J2004 Workshop (in Japanese). Kanzo 2005;46:85-90.

17 Hillman L, Gottfried M, Whitsett M, Rakela J, Schilsky M, Lee WM, Ganger D: Clinical features and outcomes of complementary and alternative medicine induced acute liver failure and injury. Am J Gastroenterol 2016;111:958-965. 


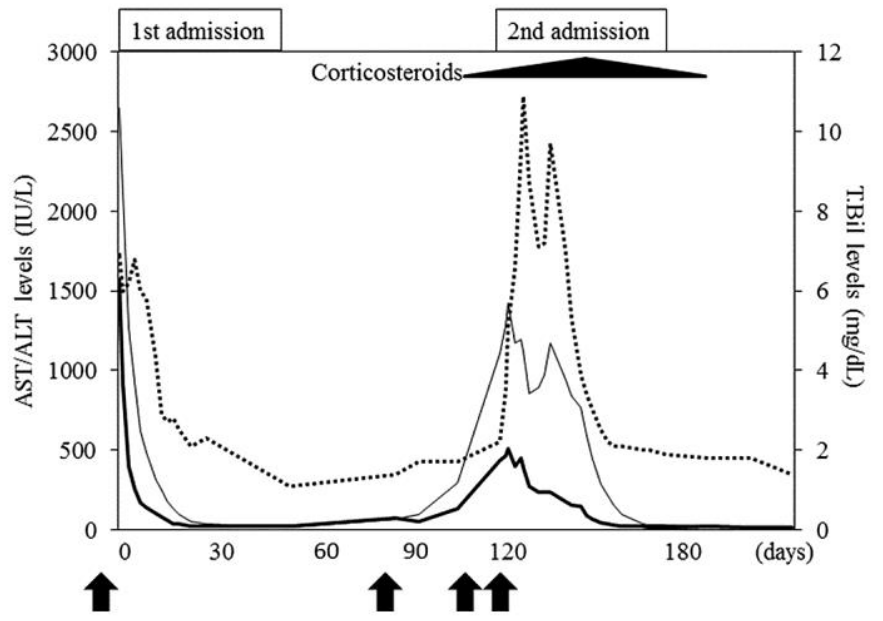

Fig. 1. Time course of liver function in relation to taking complementary and alternative medicines (LEVERCOL ${ }^{\circledR}$ and Jacko ${ }^{\circledR}$ ) (black arrows). Aspartate aminotransferase (AST), alanine transaminase (ALT) and total bilirubin (T.Bil) levels are shown by the bold line, black line, and dotted line, respectively. Liver dysfunction occurred after taking these medicines.
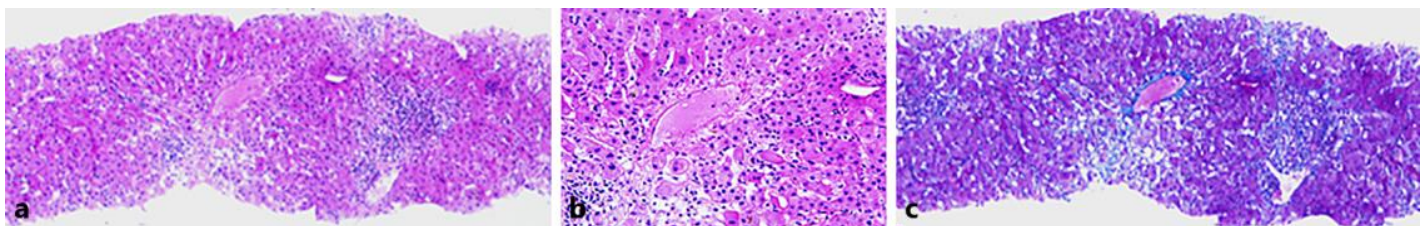

Fig. 2. The ultrasound-guided liver biopsy on the first admission revealed hepatic inflammation around the central vein with a ceroid granule ( $a$, hematoxylin and eosin staining, $\times 40$; $\mathbf{b}$, hematoxylin and eosin staining, $\times 100$ ). The hepatic architecture was preserved and findings of cirrhosis were not observed (c, Azan staining, $\times 40$ ).
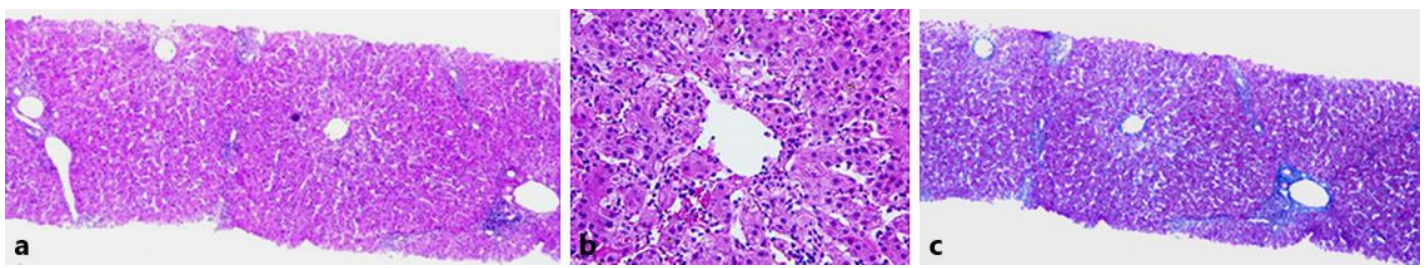

Fig. 3. The ultrasound-guided liver biopsy on the second admission showed similar findings to the first one. The hepatic architecture was preserved and findings of cirrhosis were not observed. The biopsy specimens were compatible with acute hepatitis caused by drugs ( $a$, hematoxylin and eosin staining, $\times 40$; $\mathbf{b}$, hematoxylin and eosin staining, $\times 100$; c, Azan staining, $\times 40$ ). 
Takahashi et al.: Drug-Induced Liver Injury Associated with Complementary and

Alternative Medicines

Table 1. The laboratory data of the patient on the first admission

\begin{tabular}{ll|ll|ll}
\hline Item & Value & Item & Value & Item & Value \\
\hline WBC & $4,500 / \mu \mathrm{L}$ & TP & $7.6 \mathrm{~g} / \mathrm{dL}$ & IgM anti-HAV & negative \\
RBC & $533 \times 10^{4} / \mu \mathrm{L}$ & Alb & $4.9 \mathrm{~g} / \mathrm{dL}$ & HBsAg & negative \\
Hemoglobin & $15.8 \mathrm{~g} / \mathrm{dL}$ & UN & $11 \mathrm{mg} / \mathrm{dL}$ & anti-HBs & negative \\
Hematocrit & $46.7 \%$ & Cre & $0.76 \mathrm{mg} / \mathrm{dL}$ & anti-HBc & negative \\
Platelets & $20.0 \times 10^{4} / \mu \mathrm{L}$ & ESR & $2 \mathrm{~mm} / 1 \mathrm{~h}$ & IgM anti-HBc & negative \\
PT & $73 \%$ & CRP & $0.1 \mathrm{mg} / \mathrm{dL}$ & HBV DNA & negative \\
PT-INR & 1.18 & AFP & $2.9 \mathrm{ng} / \mathrm{mL}$ & anti-HCV & negative \\
AST & $1,570 \mathrm{IU} / \mathrm{L}$ & IgG & $1,452 \mathrm{mg} / \mathrm{dL}$ & HCV RNA & negative \\
ALT & $2,650 \mathrm{IU} / \mathrm{L}$ & IgM & $92 \mathrm{mg} / \mathrm{dL}$ & IgA anti-HEV & negative \\
LDH & $524 \mathrm{IU} / \mathrm{L}$ & IgA & $235 \mathrm{mg} / \mathrm{dL}$ & IgG anti-EBV EBNA & positive \\
ALP & $640 \mathrm{IU} / \mathrm{L}$ & anti-nuclear antibody & negative & IgM anti-EBV VCA & negative \\
$\gamma$-GTP & $195 \mathrm{IU} / \mathrm{L}$ & anti-mitochondria M2 & negative & IgG anti-EBV VCA & negative \\
T.BIL & $6.9 \mathrm{mg} / \mathrm{dL}$ & anti-smooth muscle & negative & IgM anti-CMV & negative \\
D.BIL & $4.5 \mathrm{mg} / \mathrm{dL}$ & PR3-ANCA & negative & IgM anti-VZV & negative \\
T.CHO & $105 \mathrm{mg} / \mathrm{dL}$ & IgM anti-HSV & negative & anti-HIV & negative \\
\hline
\end{tabular}

AST, aspartate aminotransferase; ALT, alanine transaminase; LDH, lactate dehydrogenase; ALP, alkaline phosphatase; $\gamma$-GTP, $\gamma$-glutamyltransferase; T.BIL, total bilirubin; D.BIL, direct bilirubin; TP, total protein; Alb, albumin; T.CHO, total cholesterol; UN, urea nitrogen; Cre, creatinine; WBC, white blood cell count; RBC, red blood cell count; PT, prothrombin time; PT-INR, PT international normalized ratio; AFP, $\alpha$-fetoprotein; ESR, erythrocyte sedimentation rate; CRP, C-reactive protein; anti-HAV, anti-hepatitis A virus antibody; HBsAg, hepatitis B virus surface antigen; anti-HBs, anti-hepatitis B virus surface antibody; anti-HBc, antihepatitis B virus core antibody; anti-HCV, anti-hepatitis C virus antibody; anti-HEV, anti-hepatitis E virus antibody; anti-EBV EBNA, anti-Epstein-Barr nuclear antigen antibody; anti-EBV VCA, anti-Epstein-Barr viral capsid antigen antibody; anti-CMV, anti-cytomegalovirus antibody; anti-VZV, anti-varicella-zoster virus antibody; anti-HIV, anti-human immunodeficiency virus antibody; PR3-ANCA, proteinase-3-antineutrophil cytoplasmic antibody; anti-HSV, anti-herpes simplex antibody. 


\section{Case Reports in Gastroenterology}

Takahashi et al.: Drug-Induced Liver Injury Associated with Complementary and

Alternative Medicines

Table 2. The laboratory data of the patient on the second admission

\begin{tabular}{|c|c|c|c|c|c|}
\hline Item & Value & Item & Value & Item & Value \\
\hline WBC & $5,200 / \mu \mathrm{L}$ & $\mathrm{TP}$ & $7.7 \mathrm{~g} / \mathrm{dL}$ & IgM anti-HAV & negative \\
\hline $\mathrm{RBC}$ & $467 \times 10^{4} / \mu \mathrm{L}$ & Alb & $5.0 \mathrm{~g} / \mathrm{dL}$ & HBsAg & negative \\
\hline Hemoglobin & $15.5 \mathrm{~g} / \mathrm{dL}$ & UN & $13 \mathrm{mg} / \mathrm{dL}$ & anti-HBs & negative \\
\hline Hematocrit & $44.7 \%$ & Cre & $0.75 \mathrm{mg} / \mathrm{dL}$ & anti-HBc & negative \\
\hline Platelets & $11.6 \times 10^{4} / \mu \mathrm{L}$ & ESR & $2 \mathrm{~mm} / 1 \mathrm{~h}$ & IgM anti-HBc & negative \\
\hline PT & $73 \%$ & CRP & $0.1 \mathrm{mg} / \mathrm{dL}$ & HBV DNA & negative \\
\hline PT-INR & 1.17 & AFP & $2.5 \mathrm{ng} / \mathrm{mL}$ & anti-HCV & negative \\
\hline AST & $438 \mathrm{IU} / \mathrm{L}$ & IgG & $1,219 \mathrm{mg} / \mathrm{dL}$ & HCV RNA & negative \\
\hline ALT & 1,104 IU/L & IgM & $63 \mathrm{mg} / \mathrm{dL}$ & IgA anti-HEV & negative \\
\hline LDH & 238 IU/L & $\operatorname{IgA}$ & $193 \mathrm{mg} / \mathrm{dL}$ & IgG anti-EBV EBNA & positive \\
\hline ALP & $488 \mathrm{IU} / \mathrm{L}$ & anti-nuclear antibody & negative & IgM anti-EBV VCA & negative \\
\hline$\gamma$-GTP & $119 \mathrm{IU} / \mathrm{L}$ & anti-mitochondria M2 & negative & IgG anti-EBV VCA & negative \\
\hline T.BIL & $2.2 \mathrm{mg} / \mathrm{dL}$ & anti-smooth muscle & negative & IgM anti-CMV & negative \\
\hline D.BIL & $0.5 \mathrm{mg} / \mathrm{dL}$ & TSH & $1.749 \mu \mathrm{IU} / \mathrm{mL}$ & IgM anti-VZV & negative \\
\hline T.CHO & $152 \mathrm{mg} / \mathrm{dL}$ & anti-HIV & negative & IgM anti-HSV & negative \\
\hline
\end{tabular}

AST, aspartate aminotransferase; ALT, alanine transaminase; LDH, lactate dehydrogenase; ALP, alkaline pho sphatase; $\gamma$-GTP, $\gamma$-glutamyltransferase; T.BIL, total bilirubin; D.BIL, direct bilirubin; TP, total protein; Alb, albumin; T.CHO, total cholesterol; UN, urea nitrogen; Cre, creatinine; WBC, white blood cell count; RBC, red blood cell count; PT, prothrombin time; PT-INR, PT international normalized ratio; AFP, $\alpha$-fetoprotein; ESR, erythrocyte sedimentation rate; CRP, C-reactive protein; anti-HAV, anti-hepatitis A virus antibody; $\mathrm{HBsAg}$, hepatitis B virus surface antigen; anti-HBs, anti-hepatitis B virus surface antibody; anti-HBc, anti-hepatitis B virus core antibody; anti-HCV, anti-hepatitis $\mathrm{C}$ virus antibody; anti-HEV, anti-hepatitis E virus antibody; anti-EBV EBNA, anti-EpsteinBarr nuclear antigen antibody; anti-EBV VCA, anti-Epstein-Barr viral capsid antigen antibody; anti-CMV, anticytomegalovirus antibody; anti-VZV, anti-varicella-zoster virus antibody; anti-HIV, anti-human immunodeficiency virus antibody; TSH, thyroid stimulating hormone; anti-HSV, anti-herpes simplex antibody. 